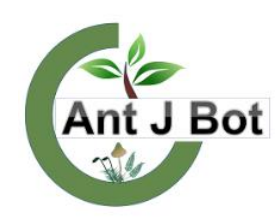

Received : 27.07.2021 Accepted : 03.09.2021 Online : : 11.09 .2021

\section{A new record for the Physalacriaceae family in Turkey}

\author{
Derya KAPLAN ${ }^{1} \odot$, Yasin UZUN ${ }^{2 *} \odot$, Abdullah KAYA ${ }^{3} \odot$ \\ ${ }^{1}$ Mut Karacaoğlan Secondary School, Mersin, Turkey \\ ${ }^{2}$ Karamanoğlu Mehmetbey University, Ermenek Uysal \& Hasan Kalan Health Services Vocational School, Dpt. \\ of Pharmacy Services, Karaman, Turkey \\ ${ }^{3}$ Gazi University, Science Faculty, Department of Biology, Ankara, Turkey \\ *yuclathrus@gmail.com, ${ }^{1}$ silifkelim33@gmail.com, ${ }^{3}$ kayaabd@hotmail.com
}

\section{Türkiye'deki Physalacriaceae familyası için yeni bir kayıt}

\begin{abstract}
Cryptomarasmius minutus (Peck) T.S. Jenkinson \& Desjardin, is given as new record for the mycobiota of Turkey with a short description and figures related to its macro and micromorphology. This species is the second member of the genus Cryptomarasmius T.S. Jenkinson \& Desjardin in Turkey and characterized by small, red-brown pileus, distant, often reduced lamellae, ellipsoid to narrowly ellipsoid basidiospores, and the presence of pileocystidia, dimorphic cheilocystidia, pleurocystidia, and caulocystidia.
\end{abstract}

Key words: Agaricales, Basidiomycota, biodiversity, new record, taxonomy

Özet: Cryptomarasmius minutus (Peck) T.S. Jenkinson \& Desjardin, kısa bir betimleme ve makro ve mikromorfolojisine ilişkin şekillerle Türkiye mikobiyotası için yeni kayıt olarak verilmiştir. Bu tür Cryptomarasmius T.S. Jenkinson \& Desjardin cinsinin Türkiye'deki ikinci üyesidir, ve küçük, kırmızı-kahverengi şapka, aralıklı, çoğunlukla indirgenmiş lameller, elipsoit veya dar elipsoit bazidiyosporlar, ve pilosistidlerin, çifte morfolojide cheilosistidlerin, ve caulosistidlerin varlığı ile karakterizedir.

Anahtar Kelimeler: Agaricales, Basidiomycota, biyoçeşitlilik, yeni kayıt, taksonomi

Citation: Kaplan D, Uzun Y, Kaya A (2021). A new record for the Physalacriaceae family in Turkey. Anatolian Journal of Botany 5(2): 120-123.

\section{Introduction}

Cryptomarasmius T.S. Jenkinson \& Desjardin is an agaricoid fungal genus in the family Physalacriaceae. It was first proposed by Thomas S. Jenkinson \& Dennis E. Desjardin (Jenkinson et al., 2014). All the members of the genus were previously placed in Marasmius Fr., section Hygrometrici characterized by a smaller pileus that is wellpigmented and broom cells mostly of the Rotalis-type or often in a combination with smooth cells, free to adnate attachment of lamellae, absence of collarium, a central and insititious stipe, usually presence of pleuro- and cheilocystidia, neither amyloid or dextrinoid nature of the pileus, lamellae or stipe trama, and medium-sized basidiospores (Singer, 1976; Dutta and Acharya, 2018).

Index Fungorum (2021) lists 15 Cryptomarasmius species among which only $C$. corbariensis (Roum.) T.S. Jenkinson $\&$ Desjardin is known to exist in Turkey. This species was first reported from by Nizip district of Gaziantep province by Uzun et al. (2017). Within the following year Bozok et al. (2018) also presented this species from Osmaniye province with molecular data.

Here we present $C$. minutus (Peck) T.S. Jenkinson \& Desjardin as the second member of the genus Cryptomarasmius in Turkey. The current checklist (Sesli et al., 2020) and the latest contributions (Akçay, 2020; Çağli and Öztürk, 2020; Keleş, 2020; Sesli, 2020; Yeşil et al., 2020; Acar et al., 2021; Doğan, 2021; Kaygusuz et al., 2021; Sesli, 2021; Uzun, 2021) on Turkish mycobiota indicate that, C. minutus hadn't been reported from Turkey before, and this is the first distributional record of this species in Turkey. The study aims to make a contribution to the mycobiota of Turkey.

\section{Materials and Method}

The basidiocarps of $C$. minutus were collected during a field study in Silifke district of Mersin province. The material was photographed in the field using a Sony HX400V digital camera and extensive notes on the basidiomata were taken before drying. Then the collected samples were transferred to the fungarium within paper boxes and dried in an air conditioned room. Microscopic investigations were performed under a Nikon Eclipse Ci-S trinocular microscope by preparing free-hand sections of dry specimens. Identification was performed by comparing the obtained data with the available literature (Gilliam, 1976; Breitenbach and Kränzlin, 1991; Antonin and Noordeloos, 2010).

The specimens are kept at Karamanoğlu Mehmetbey University, Science Faculty, Department of Biology, Karaman.

\section{Results}

Fungi R.T. Moore

Basidiomycota R.T. Moore

Agaricales Underw.

Physalacriaceae Corner

Cryptomarasmius minutus (Peck) T.S. Jenkinson \& Desjardin, Mycologia 106(1): 92 (2014)

Syn: [Chamaeceras capillipes (Sacc.) Kuntze, Chamaeceras minutus (Peck) Kuntze, Marasmius capillipes Sacc., Marasmius capillipes var. macrosporus Kühner, Marasmius minutus Peck]

Macroscopic features: Pileus 0.6-2.5 mm in diam., almost hemispherical to deeply convex when young, becomes 
conic convex, plano-convex to plane at maturity, often with a depressed central disc, radially striate or distantly striate, when fresh pale red brown with a darker centre, dark brown when dry, margin incurved when young, undulating at maturity. Flesh membranous. Lamellae almost invisible when young, distant, free to narrowly adnexed, without collar, whitish to light brownish. Taste and odor not distinguishable. Stipe 5-19.5 × 0.05-0.2 mm, central, filiform, equal, curved, twisted or curled, solid, brown to black-brown (Fig 1), somewhat lighter to whitish toward the pileus.

Microscopic features: Basidia 16-23 $\times$ 5-7.5 $\mu \mathrm{m}$, cylindric-clavate, with 4 -spored with a basal clamp (Fig 2a), basidioles $11-19 \times 3.5-8.5$, cylindrical-clavate to clavate. Basidiospores 6-8 $\times 2.2-4 \mu \mathrm{m}$, ellipsoid to narrowly ellipsoid, some amygdaliform, smooth, hyaline, inamyloid (Fig 2b). Pileipellis hymeniform, mainly composed of broadly clavate to pyriform, vesiculose or cylindrical broom cells of the Rotalis-type 10-21 × 6-15 $\mu$, with numerous 0.8-2.3 long projections (Fig 2c). Pileocystidia 17-26 $\times$ 4-6.5 $\mu \mathrm{m}$ (Fig 2d), interspeaded among pileipellis. Cheilocystidia of two types: 1-broom cells of Rotalis-type, 10-16.5 $\times 6-11 \mu \mathrm{m}$, broadly clavate to vesiculose with 0.7 $2 \mu \mathrm{m}$ long projections; 2 - fusiform to lageniform, smooth, 20-31 × 6.5-13 $\mu \mathrm{m}$ (Fig. 2e). Pleurocystidia 17-30 $\times 4-8 \mu \mathrm{m}$ fusiform, ventricose or lageniform, smooth (Fig 2f).

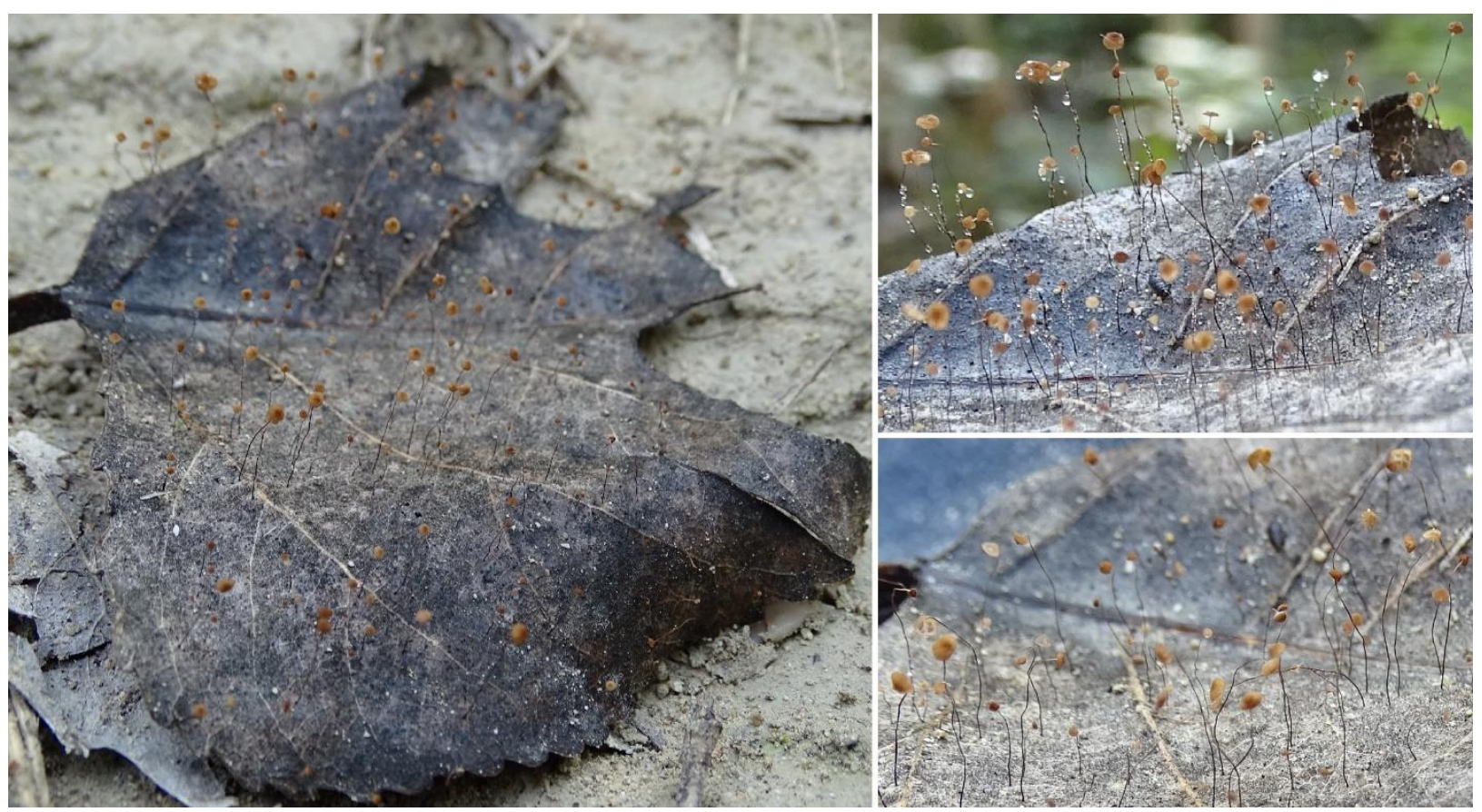

Figure 1. Basidiocarps of Cryptomarasmius minutus
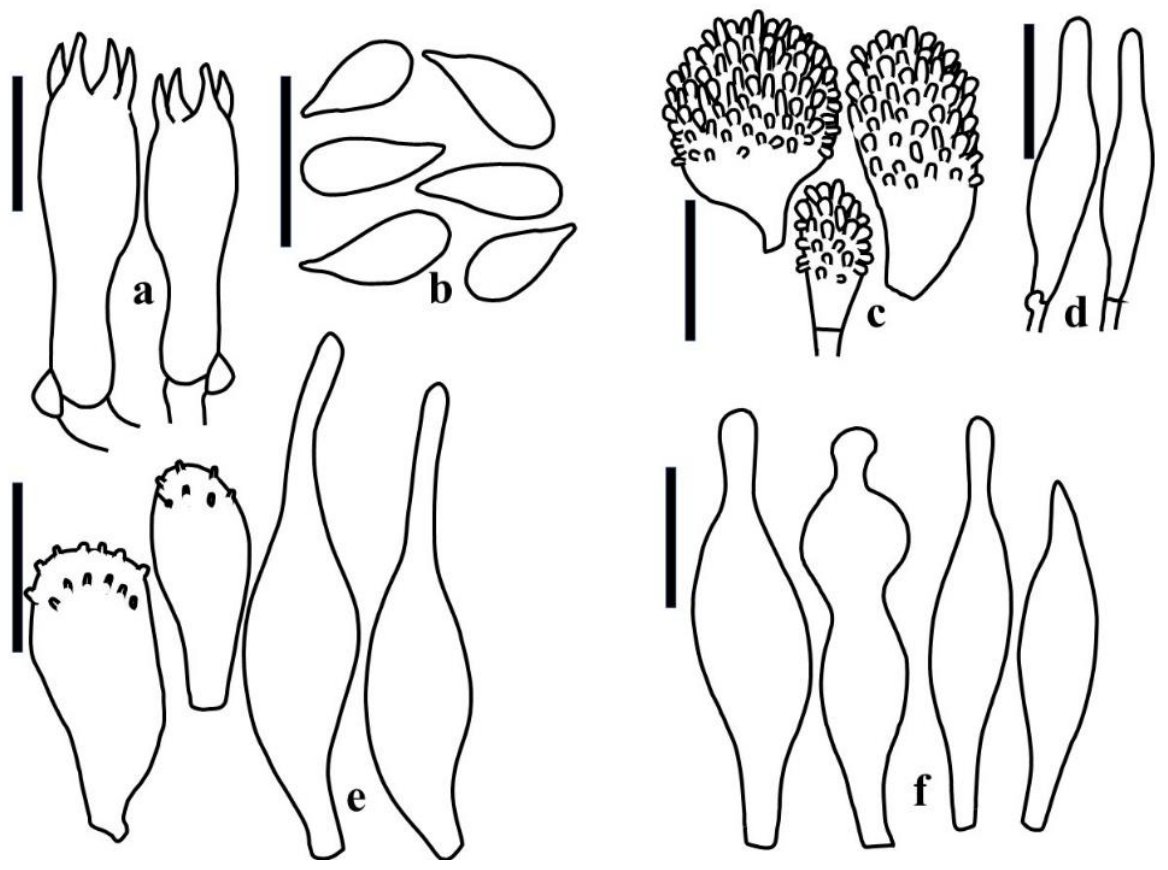

Figure 2. Basidia (a), basidiospores (b), pileipellis (c), pileocystidia (d), cheilocystidia (e) and pleurocystidia (f) of Criptomarasmius minutus (bars: $10 \mu \mathrm{m}$ ) 
Cryptomarasmius minutus was reported to grow on fallen or decaying leaves of various deciduous trees such as Populus L., Salix L., Fraxinus L., Ulmus L., Acer L., Syringa L, especially of Populus and Salix spp. in damp, shady places (Gilliam, 1976; Breitenbach and Kränzlin, 1991; Antonin and Noordeloos, 2010; Jenkinson et al., 2014).

Specimens examined: Mersin, Silifke, Değirmendere village, Göksu river bank, on fallen Populus sp. leaves. $36^{\circ} 24^{\prime} \mathrm{N}-33^{\circ} 48^{\prime} \mathrm{E}, 40 \mathrm{~m}, 09.11 .2019$, DerKap-305.

\section{Discussions}

Cryptomarasmius minutus was presented as a new member of the genus Cryptomarasmius in Turkey. In general, macro and micromorphology are in agreement with those given in literature (Gilliam, 1976; Breitenbach and Kränzlin, 1991; Antonin and Noordeloos, 2010; Jenkinson et al., 2014).

Though it has rarely been recorded, $C$. minutus is thought to be a widespread species in the temperate zone of Northern hemisphere and has been recorded from many European countries such as Austria, Czech Republic, France, Germany, Italy, Netherlands and Spain. Due to the tiny and easily drying-up fruit bodies which become almost indistinguishable from the substrate, it is an easily overlooked species (Antonin and Noordeloos, 2010).
Marasmius pseudominutus Singer and M. pichinchensis Singer are similar to $C$. minutus. But slightly larger spores $(6.5-10 \times 4.0-5.0 \mu \mathrm{m})$ of $M$. pseudominutus and the presence of rhizomorphs from which stipes arise, and the monotypic cheilocystidia of $M$. pichinchensis differ them from C. minutus (Antonin and Noordeloos, 2010).

Cryptomarasmius minutus is the second member of the genus Cryptomarasmius in Turkey. The previously reported Turkish species of the genus, $C$. corbariensis, have a larger fruit body (a pileus of 2-9 $\mathrm{mm}$ in diameter and a stipe of $10-30 \times 0.2-0.3 \mathrm{~mm})$, larger basidia $(22-30 \times 8-9.5$ $\mu \mathrm{m})$ and larger basidiospores $(8-103.5-5.5 \mu \mathrm{m})$, though most other micro characters agree. The substrate of $C$. corbariensis was also different (Antonin, 2007; Uzun et al., 2017). Cryptomarasmius corbariensis was reported on rotting Olea L. sp. leaves, while C. minutus is largely confined to fallen Populus or Salix sp. leaves, and was collected on rotting Populus sp. leaves (Uzun et al., 2017; Henrici, 2018).

\section{Conflict of Interest}

Authors have declared no conflict of interest.

\section{Authors' Contributions}

The authors contributed equally.

\section{References}

Acar İ, Uzun Y, Kalmer A, Dizkırıcı Tekpınar A, Öğün Y (2021). A new record for Turkish mycobiota from Selim (Kars) district. The Journal of Fungus 12(1): 65-70.

Akçay ME (2020). A new record for the Mycota of Turkey. Anatolian Journal of Botany 4(1): 8-10.

Antonin V (2007). Fungus Flora of Tropical Africa, Vol 1, monograph of Marasmius, Gloiocephala, Palaeocephala and Setulipes in Tropical Africa. National Botanic Garden of Belgium.

Antonin V, Noordeloos ME (2010). A monograph of marasmioid and collybioid fungi in Europe. Eching: IHV Verlag.

Bozok F, Taşkın H, Büyükalaca S, Doğan HH, Assyov B (2018). Cryptomarasmius corbariensis (Physalacriaceae, Agaricales) in Turkey with first molecular data on the species from Eurasia. Nova Hedwigia 107 (1-2): 110-116.

Breitenbach J, Kränzlin F (1991). Fungi of Switzerland, Vol.3. Lucerne: Verlag Mykologia.

Çağli A, Öztürk A (2020). Macromycetes determined in Muradiye (Van) district. Anatolian Journal of Botany 4(1): 57-64.

Doğan HH (2021). A new truffle species addition, Tuber macrosporum Vittad., to Turkish mycota. Trakya University Journal of Natural Sciences 22(2): $\mathrm{xx}-\mathrm{xx}$ (in print)

Dutta AK, Acharya K (2018). First record of fungus Cryptomarasmius T.S. Jenkinson \& Desjardin (Physalacriaceae: Agaricales: Basidiomycota) from India. Journal of Threatened Taxa 10(3): 11464-11469.

Gilliam MS (1976). The genus Marasmius in the Northeastern United States and adjacent Canada. Mycotaxon 4(1): 1-144.

Henrici A (2018). Notes and records. Field Mycology 19(3): 105-107.

Index Fungorum. (2021). http://www.indexfungorum.org/names/Names.asp / [07 July 2021].

Jenkinson TS, Perry BA, Schaefer RE, Desjardin DE (2014). Cryptomarasmius gen. nov. established in the Physalacriaceae to accommodate members of Marasmius section Hygrometrici. Mycologia 106(1): 86-94.

Kaygusuz O, Türkekul İ, Knudsen H, Menolli N (2021). Volvopluteus and Pluteus section Pluteus (Agaricales: Pluteaceae) in Turkey based on morphological and molecular data. Turkish Journal of Botany 45(3): 224-242.

Keleş A (2020). Türkiye mikotası için yeni bir cins (Gerronema Singer) kayd1. The Journal of Fungus 11(2): 168-171.

Sesli E (2020). Presence of Cortinarius atroalbus M.M.Moser and C. duracinobtusus Rob. Henry (Basidiomycota, Cortinariaceae) in Turkey. Anatolian Journal of Botany 4(2): 92-95.

Sesli E (2021). First records of Cortinarius leucoluteolus and C. roseocastaneus from Turkey. The Journal of Fungus 12(1): 15-18.

Sesli E, Asan A, Selçuk F. (edlr.) Abacı Günyar Ö, Akata I, Akgül H, Aktaş S, Alkan S, Allı H, Aydoğdu H, Berikten D, Demirel K, Demirel R, Doğan HH, Erdoğdu M, Ergül CC, Eroğlu G, Giray G, Halikî Uztan A, Kabaktepe Ş, Kadaifçiler D, Kalyoncu F, Karaltı İ, Kaşık G, Kaya A, Keleş A, Kırbağ S, Kıvanç M, Ocak İ, Ökten S, Özkale E, Öztürk C, Sevindik M, Şen B, Şen İ, Türkekul İ, Ulukapı M, Uzun Ya, Uzun Yu, Yoltaş A (2020). Türkiye Mantarları Listesi. Ali Nihat Gökyiğit Vakfi Yayını. İstanbul. 
Kaplan et al. - A new record ...

Singer R (1976). Flora Neotropica Monograph 17 Marasmieae (Basidiomycetes: Tricholomataceae). New York: New York Botanical Garden.

Uzun Y (2021). Spathularia nigripes and Trichoglossum walteri newly recorded from Turkey. Mycotaxon 136(1): 229-234.

Uzun Y, Kaya A, Karacan İH, Yakar S (2017). New additions to Turkish Agaricales. Biological Diversity and Conservation 10(2): 8-13.

Yeşil A, Uzun Y, Akçay ME, Sadullahoğlu C, Acar İ (2020). Siirt (Merkez) Yöresinde Belirlenen Makromantarlar. Yüzüncü Y1l Üniversitesi Fen Bilimleri Enstitüsü Dergisi 25(1): 32-40. 